\title{
11. EARLY CRETACEOUS PALYNOMORPHS OF THE WESTERN PACIFIC OCEAN ${ }^{1}$
}

\author{
Gabi Ogg 2
}

\begin{abstract}
Lower Cretaceous and Jurassic sediments from Ocean Drilling Program Leg 129 (Sites 800, 801, and 802) and Deep Sea Drilling Project Sites 167, 195, 196, and 463 were analyzed for palynomorphs. In contrast to Atlantic occurrences, all Cretaceous pelagic sediments at these sites in the Pacific are barren of preserved palynomorphs. This absence of palynomorphs appears to be independent of facies, sedimentation rate, paleodepth, and paleolatitude. Except for one sample, the dinocyst-bearing sediments also contain spores and pollen grains. The only palynomorphs observed were in redeposited material having sources near former emergent seamounts.

Among the dinoflagellate cysts at Site 802, Dingodinium cerviculum, Odontochitina operculata, Canninginopsis colliveri, and Oligosphaeridium complex are the most important species. Based on the presence of these species and their known biostratigraphic ranges, this basal interval of Site 802 is considered to be Aptian/earliest Albian in age.

The lack of dinocysts within the Pacific pelagic sediments may be the result of ubiquitous oxygenated bottom waters throughout the Cretaceous or may indicate that open-marine dinoflagellate populations in this ocean did not produce cysts.
\end{abstract}

\section{INTRODUCTION}

Sporopollenic palynomorphs (dinoflagellate cysts, spores, pollen grains) are important microfossils used for biostratigraphy and paleoecology in marine and terrestrial environments. Dinocysts are especially important for biostratigraphic studies in Mesozoic and Tertiary epicontinental seas and in the Atlantic.

Palynomorphs from the Pacific are mainly described from the Tertiary (Ballog and Malloy, 1978; Koreneva, 1980) and Quaternary (Wiseman, 1976). Investigations of Jurassic/Cretaceous palynomorphs in the Pacific Ocean region are very rare. The only well studied areas are Australia (e.g., Cookson and Eisenack, 1958, 1960, 1962; Burger, 1980, Jell (ed.), 1987), Papua New Guinea (e.g., Davey, 1988) and New Zealand (e.g., Helby et al., 1988).

Ocean Drilling Program(ODP) Leg 129 in the western Pacific offered an opportunity to investigate dinocysts of an open ocean environment.

The objective of this study was to investigate the palynomorph content of the three sites drilled during Leg 129 and to compare the results with other Deep Sea Drilling Project (DSDP) sites in the Pacific.

\section{METHODS}

A suite of 344 samples from Leg 129 and a total of 44 samples from Leg 17 (Site 167), Leg 20 (Sites 195 and 196), and Leg 62 (Site 463) were analyzed for palynomorphs.

All samples were processed using standard palynological preparation techniques. Hydrochloric and hydrofluoric acid were used to remove carbonates and silicates. Half of the remaining residue from each sample was oxidized with nitric acid to remove fine organic detritus to facilitate identification of the palynomorphs. Two slides were prepared from the nonoxidized residue and four from the oxidized residue. When palynomorphs were present, 500 specimens were determined in each oxidized sample, and in addition one slide with nonoxidized organic residue was examined to obtain the complete palynomorph assemblage. Acritarchs and most of the sporomorphs were determined only to generic level.

\footnotetext{
'Larson, R. L.. Lancelot. Y., et al., 1992. Proc. ODP, Sci. Results, 129: College Station, TX (Ocean Drilling Program).

${ }^{2}$ Institut und Museum für Geologie und Paläontologie, Sigwartstr. 10, W-7400 Tübingen, Federal Republic of Germany. (Present address: Department of Earth and Atmospheric Sciences, Purdue University, West Lafayette, IN 47907. U.S.A.)
}

Age assignments were made by comparison with the Australian palynological zonation scheme by Helby et al. (1987).

The slides are deposited at the Institut und Museum für Geologie und Paläontologie of the University of Tübingen.

\section{PALYNOMORPH OCCURRENCES}

\section{Site 167}

Site 167 is located on the Magellan Rise (Fig. 1). Eighteen samples (167-66-1, 135-136 cm, through 167-94-1, 93-94 cm) were taken from Tithonian/Berriasian to Turonian light-colored limestone and chert (Shipboard Scientific Party, 1973a).

Only the lowest sample $(167-94-1,93-94 \mathrm{~cm})$ yielded a few poorly preserved dinoflagellate cysts. The assemblage did not allow an age assignment, Wallodinium krutzschii is known to occur from the lower Tithonian to Aptian. Core 167-94 is dated by nannofossils as Tithonian/Berriasian (Roth, 1973).

\section{Site 195 and Site 196}

Sites 195 and 196 are located on the abyssal floor east of Izu-Bonin Trench (Fig. 1). Two samples were collected at Site 195 (195B-2-CC and 195B-3-1, 112-113 cm) from cherts of Valanginian to Hauterivian age (Shipboard Scientific Party, 1973b).

At Site 196 two samples (196-3-1, 123-125 cm, and 196-4-1, 106$107 \mathrm{~cm}$ ) were taken from gray silicious limestone and reddish chert of Jurassic to Hauterivian age (Shipboard Scientific Party, 1973c).

None of the samples from Sites 195 and 196 yielded any palynomorphs.

\section{Site 463}

Site 463 is located in the northwestern region of the Mid-Pacific Mountains (Fig. 1). Twenty-two samples (463-48-2, 62-63 cm, through 463-86-1, 90-91 cm) were collected from sediments of Barremian to Albian age (Shipboard Scientific Party, 1981). The multicolored pelagic limestone and silicified limestone of early Aptian to middle Albian (Samples 463-48-2, 62-63 cm, through 463-66-1, 46-47 cm) were barren. Samples 463-67-2, 97-98 cm, through 463-86-1, 90-91 cm, mainly taken from calcareous turbidite and debris-flow deposits of Barremian to early Aptian age, yielded only a few palynomorphs. The two samples (463-69-1, 19-29 cm, and 463-76-1, 124-125 cm) taken from limestones within this interval were barren. 


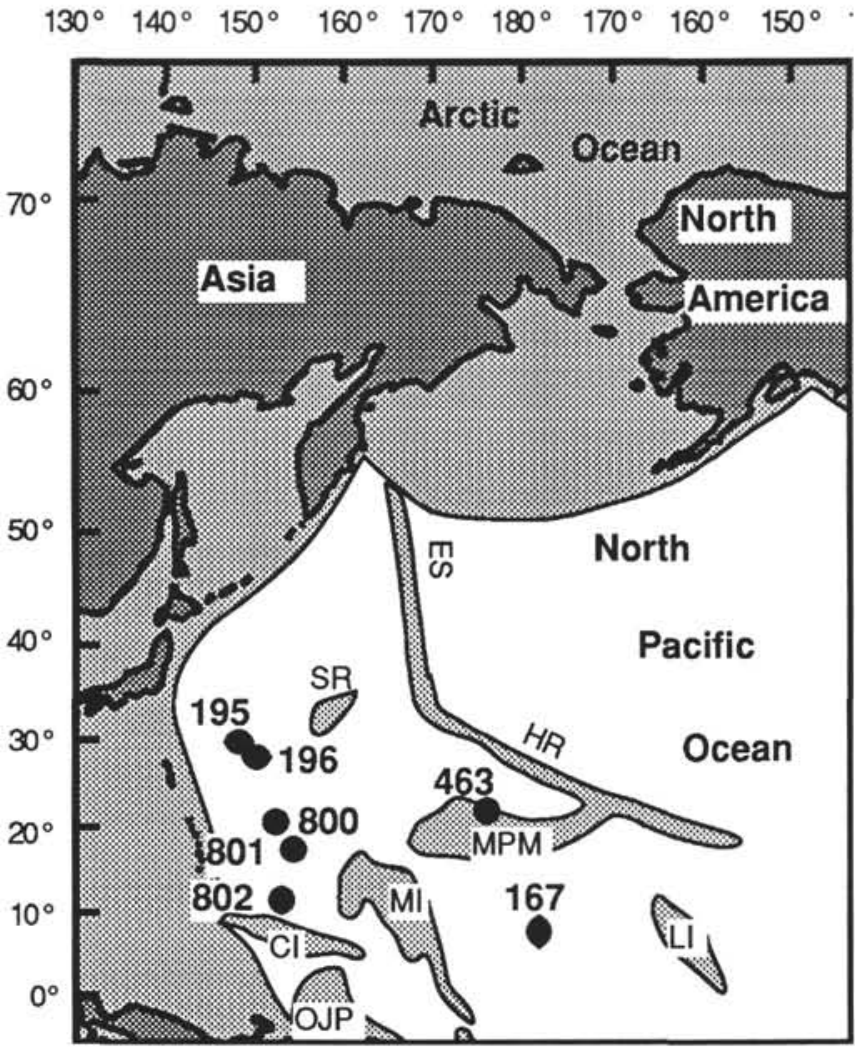

Figure 1. Location of Sites $167,195,196,463,800,801$, and 802 . Shaded areas represent volcanic edifices with thickened crustal sections, as well as the younger areas beyond the Pacific subduction zones. Unshaded areas represent normal Pacific oceanic crust. (Abbreviations are as follows: $\mathrm{CI}=$ Caroline Islands, $\mathrm{ES}=$ Emperor Seamounts, $\mathrm{HR}=$ Hawaiian Ridge, $\mathrm{LI}=$ Line Islands, $\mathrm{MI}=$ Marshall Islands, $\mathrm{MPM}=$ Mid-Pacific Mountains, OJP $=$ Ontong Java Plateau, SR = Shatsky Rise.)

\section{Biostratigraphy of Site 463}

The sampled interval of $62-463-73 \mathrm{R}-1,124-125 \mathrm{~cm}$, through 62-463-86R-1, 90-91 cm, is dated as Barremian from nannoplankton (Cepek, 1981). Magnetic polarity Chron M1r of late Barremian age (Lowrie et al., 1980) occurs in Cores 62-463-77 through 62-463-78 (Sayre, 1981). Polarity Chron M0r of basal Aptian (Ogg, 1988; Tarduno et al., 1989) is found within Core 62-463-72 (Sayre, 1981). Palynomorphs are rare and poorly preserved in this interval. The dinocyst assemblage consists mainly of Oligosphaeridium pulcherrimum, O. complex, Wallodinium krutzschii, and Fromea fragilis. The dominant sporomorphs are Cyathidites minor and Callialasporites dampieri. All these palynomorph species have a biostratigraphic range through the Early Cretaceous, and therefore a precise age assignment is not possible.

The interval of Samples 62-463-67R-2, 97-98 cm, through 62-463$71 \mathrm{R}-2,52-53 \mathrm{~cm}$, is dated as Aptian from foraminifers (Sliter, 1989). The dinocysts include Canninginopsis colliveri, Odontochitina operculata, Spiniferites spp., and Fromea fragilis. The sporomorphs are characterized by Cyathidites minor and Stereisporites antiquasporites.

Canninginopsis colliveri, Odontochitina operculata, Cyathidites minor, and Stereisporites antiquasporites are common forms throughout the Aptian, but the known range of this assemblage extends from Barremian to Cenomanian, and therefore no precise age assignment is possible only with these palynomorphs.

The occurrence of abundant spores and pollen grains supports the hypothesis of Winterer and Metzler (1984) that the volcanoes of the
Mid-Pacific Mountains were at sea level or emergent from the Barremian through Aptian.

\section{Sites 800,801 , and 802}

Three sites were drilled during Leg 129 in the western Pacific (Fig. 1): Sites 800 and 801 in the Pigafetta Basin and Site 802 in the East Mariana Basin. The main objective of these sites was to recover the oldest oceanic crust of the Pacific Plate, which was predicted to be of Jurassic age (Abrams et al., 1988).

\section{Sites 800 and 801}

The complete sedimentary sequences at Sites 800 (100 samples) and 801 (108 samples) were sampled for palynomorphs, but all samples were barren. Samples 129-800A-7R-CC through 129-800A9R-CC, taken from Campanian brown chert and porcellanite (Shipboard Scientific Party, 1990a), and 129-801B-16R-CC through 129-801B-32R-CC, taken from Oxfordian to Valanginian brown radiolarite (Shipboard Scientific Party, 1990b), yielded some amorphous organic matter.

\section{Site 802}

The whole sedimentary sequence at Site 802 was sampled (136 samples) for palynomorphs. Except for Cores 129-802A-25R and 129-802A-56R through 129-802A-57R, all cores from Site 802 are barren of palynomorphs. Sample 129-802A-25R-CC from lower Miocene-Pliocene volcaniclastic turbidites (Shipboard Scientific Party, 1990c) yields large amounts of wood fragments, plant cuticules, and a few spores and pollen grains of Miocene age. The terrestrial influx indicates that surrounding seamounts were above sea level during the Miocene. These volcaniclastic turbidites probably derived from the Caroline Rise, for example, the island of Truk, which is Miocene in age and is still above sea level today.

The fine-grained volcaniclastic turbidites and tuffaceous claystone (Shipboard Scientific Party, 1990c) of Samples 129-802A56R-4, 34-36 cm, through 129-802A-57R-2,57-61 cm (upper Aptian to Albian), yield a rich palynoflora with large amounts of plant cuticules and wood fragments. The abundance of marine and terrestrial palynomorphs is generally high, but their diversity is moderate with 28 dinocyst species and 22 sporomorph species.

Trilete spores (Cyathidites spp.) dominate the palynoflora, Callialasporites dampieri and $C$. trilobatus are rather frequent, and bisaccate pollen grains (mainly species of Alisporites and Podocarpidites) are less abundant (Fig. 2). Dinoflagellate cysts and leiosphaerid acritarchs comprise approximately $25 \%-40 \%$ of the total assemblage (Fig. 2). The dominance of sporomorphs and large amounts of wood fragments, and of well-preserved plant cuticules and tracheids, reflect original deposition in a nearshore area around emerged seamounts, from where they were transported to the present site by turbidity currents. Subsidence calculations on these seamounts indicate that either the oceanic crust in this region is of Early Cretaceous age or that there was widespread thermal uplift of this "Darwin Rise" associated with the pulse of mid-Cretaceous seamount building (McNutt et al., 1990).

\section{Biostratigraphy of Site 802}

Sporomorphs are very abundant in Samples 129-802A-56R-4, $34-36 \mathrm{~cm}$, through 129-802A-57R-2, 57-61 cm. Cyathidites minor, Callialasporites dampieri, and C. trilobatus (Pl. 1, Fig. 10) are dominant (Fig. 3), but they provide little information for age assignment. An age not older than early Aptian is suggested for this sequence by the rare occurrence of Foraminisporis asymmetricus, on the basis of comparison with Australian palynofloras (Helby et al., 1987). 


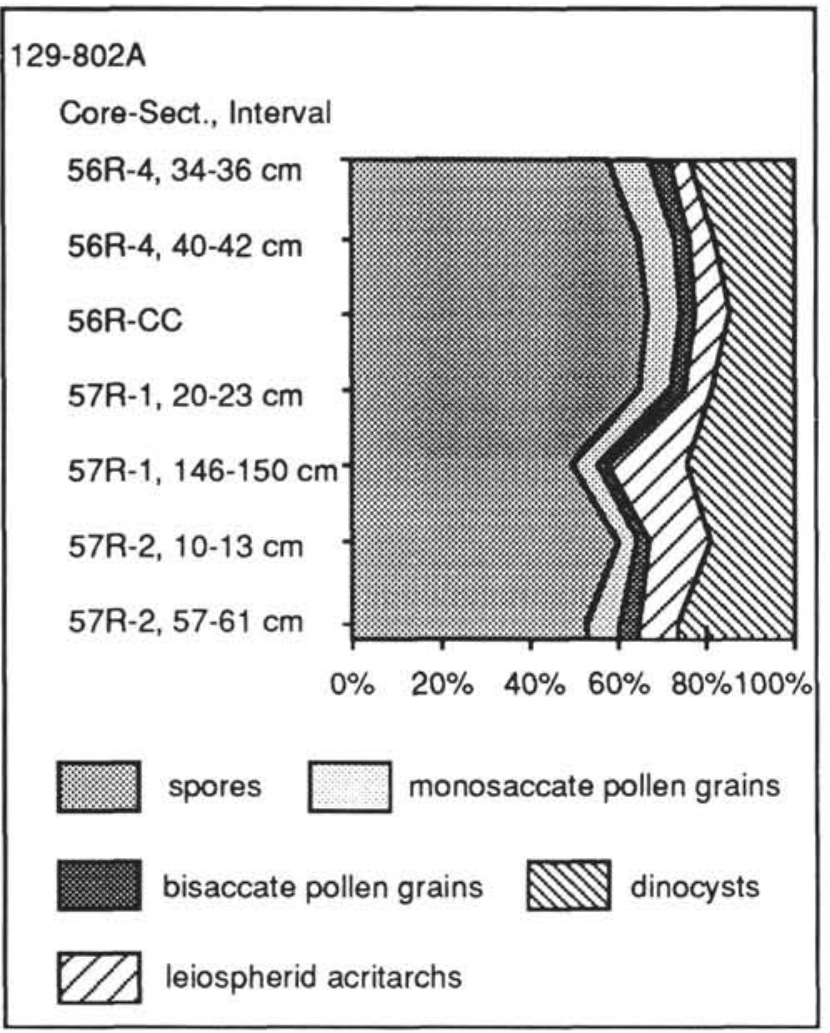

Figure 2. Palynomorph assemblage analysis of Hole 802A.

Dinoflagellate assemblages of Samples 129-802A-56R-4, 34-36 $\mathrm{cm}$, through 129-802A-57R-2, 57-61 cm, are characterized by Canninginopsis colliveri (Pl. 1, Figs. 1,6), Dingodinium cerviculum (Pl. 1, Fig. 5), Oligosphaeridium complex, (Pl. 1, Fig. 4), and Odontochitina operculata (Fig. 4). In Australia, Dingodinium cerviculum ranges from Hauterivian to earliest Albian (Helby et al., 1987). Odontochitina operculata occurs sporadically throughout the Barremian and consistently from Aptian to the Late Cretaceous. Canninginopsis colliveri, together with Dingodinium cerviculum and Muderongia tetracantha (Pl. 1, Figs. 2, 3), are "significant accessory forms" of the Diconodinium davidii interval zone (Fig. 5). A few cysts of Muderongia tetracantha were found in Sample 129-802A-57R-2,57-61 cm. Therefore, based on the presence of these species and on the absence of index species of the Heterosphaeridium superzone (Fig. 5), which ranges from the early Albian to earliest Santonian (Helby et al., 1987), this interval is considered to be Aptian/earliest Albian in age. Comparisons with nannofossils recovered from these sediments further constrain the age to latest Aptian/earliest Albian.

\section{PRESERVATION}

The absence of marine palynomorphs in most of the samples of the Pacific Ocean raises two intriguing questions.

First, was the open-ocean environment unfavorable for dinoflagellates that produce cysts? Studies of recent dinoflagellates show that most species do not form sporopollenin resting cysts and so they leave no fossil records (Dale, 1983). The majority of cyst-forming dinoflagellates in modern oceans are found in neritic environments on the shelf and upper slope. Open-ocean conditions seem to be less favorable for cyst-producing species, and the adaptive advantage of resting cysts that sink to the ocean floor is questionable (Loeblich and Loeblich, 1984). The dinoflagellate cysts of the studied Pacific samples occur predominantly in turbidites together with sporomorphs and plant fragments, which indicate an original deposition in a nearshore environment.
On the other hand, in the Atlantic Ocean at Sites 391 and 603, dinoflagellate cysts are found in open-ocean sediments (Habib, 1978; Habib and Drugg, 1987) of Late Jurassic and Early Cretaceous age. From the Valanginian onward, these sites were also situated within the range of turbidity currents, but no turbidite redeposition has been recognized in the reddish-colored to white limestones of Tithonian and Berriasian age that contain dinocysts.

Second, did postburial diagenetic factors destroy the palynomorphs? Organic matter is resistant to most acids but very sensitive to oxidizing conditions. The red coloration of radiolarites and claystones imply oxidizing bottom waters in the Pacific, which destroy the palynomorphs during early diagenesis. Depending on the time of exposure to oxidizing bottom waters, the destruction of configured organic matter varies. Within intervals deposited at a moderate sedimentation rate of $3 \mathrm{~m} / \mathrm{m}$.y. for Samples 129-800A-7RCC through 129-800A-9R-CC (Campanian) and of 7-12 m/m.y. for Samples 129-801B-16-CC through 129-801B-32R-CC (Oxfordian to Valanginian) (Shipboard Scientific Party, 1990a; Molinie and Ogg, this volume), some amorphous organic matter was found, but no identifiable palynomorphs. The oxidizing bottom waters in this part of the Pacific Ocean contradict the theory of a global anoxic event (e.g., Vogt, 1989).

In addition, the recrystallization of the original matrix at a later time will destroy organic matter (Dürr, 1988). This factor further helps to explain the absence of palynomorphs in the silicified limestones at Site 800 (Core 129-800A-13R through 129-800A-22R) and at Site 463 (Sample 463-76R-1, 124-125 cm).

These possible factors of cyst production, oxidizing bottom waters, and recrystallization, operating independently or in concert, may explain the curious lack of dinoflagellate cysts in the Pacific pelagic sediments.

\section{CONCLUSIONS}

Dinoflagellate cysts throughout the Pacific are rarely present in Jurassic or Cretaceous pelagic sediments. This absence of cysts may be due either to rarity of preservation because of destruction of the organic matter at the sediment surface or during diagenesis, or to an original lack of cyst-producing dinoflagellates in the open-ocean environment. Well-preserved palynomorphs are mainly found in turbidites derived from shallow-marine environments where conditions for cyst-forming dinoflagellates are favorable. The occurrence of sporomorphs, wood fragments, and plant cuticules at Site 802 and Site 463 give evidence for the existence of islands with dense vegetation during the Early Cretaceous.

Precise age assignment of Site 463 is not possible using palynomorphs. Volcaniclastic turbidites that directly overlie the basalts at Site 802 are dated as late Aptian/earliest Albian.

\section{ACKNOWLEDGMENTS}

I am grateful to the Ocean Drilling Program for inviting me to participate on Leg 129 and to obtain samples of Sites 167, 195, 196, and 463 . This work was supported by the Deutsche Forschungsgemeinschaft (Bonn). I want to thank H.P. Luterbacher (Tübingen) for suggesting this project and J. G. Ogg (Purdue) and the reviewers W. Brenner (Kiel), E. Masure (Paris), and E. L. Winterer (Scripps) for their helpful comments.

\section{REFERENCES}

Abrams, L. J., Larson, R. L., Shipley, T., and Lancelot, Y., 1988. Cretaceous volcanic sequences and Jurassic(?) crust in the western Pacific. Trans. Am. Geophys. Union, 69:1442.

Alberti, G., 1961. Zur Kenntnis mesozoischer und alttertiärer Dinoflagellaten und Hystrichosphaerideen von Nord- und Mitteldeutschland sowie einigen anderen europäischen Gebieten. Palaeontographica A, 116:1-58.

Backhouse, J., 1988. Late Jurassic and Early Cretaceous palynology of the Perth Basin, Western Australia. Bull. Geol. Surv. West. Aust., 135:1-233. 
Ballog, R. A., and Malloy, R. E., 1978. Neogene palynology from the southern California Continental Borderland, Site 467. Deep Sea Drilling Project Leg 63. In Yeats, R. S., Haq, B. U., et al., Init. Repts. DSDP, 63: Washington (U.S. Govt. Printing Office), 565-576.

Balme, B. E., 1957. Spores and pollen grains from the Mesozoic of Western Australia. CSIRO Fuel Res. Coal Res. Sect., 25.

Below, R., 1981. Dinoflagellaten-Zysten aus dem oberen Hauterive bis unteren Cenoman Süd-West-Marokkos. Palaeontographica B, 176:1-145.

Bolchovitina, N. A., 1961. Fossil and recent spores in the Schizaeaceae. Trudy Inst. Geol. Nauk. Mosk., 40:1-176. (in Russian)

Brenner, G. J., 1963. The spores and pollen of the Potomac group of Maryland. Dept. Geol. Mines Water Res. Bull., 27:1-215.

Burger, D., 1980. Palynology of the Lower Cretaceous of the Surat Basin. Bull. Bur. Miner. Resour., Geol. Geophys. (Aust.), 189:1-106.

Cepek, P., 1981. Mesozoic Calcareous nannoplankton stratigraphy of the central North Pacific (Mid-Pacific Mountains and Hess Rise), Deep Sea Drilling Project Leg 62. In Thiede, J., Vallier, T. L., et al., Init. Repts. DSDP, 62: Washington (U.S. Govt. Printing Office), 397-418.

Clarke, R.F.A., and Verdier, J.-P., 1967. An investigation of microplankton assemblages from the Chalk of the Isle of Wight, England. Verh. K. Nederl. Akad. Wet. Afd. Natuurkde, 24:1-96.

Cookson, I. C., 1947. Plant microfossils from the lignites of Kerguelen Archipelago. B.A.N.Z. Antarct. Res. Exped. 1929-31 Rep., Ser. A, 2:127-142.

, 1953. Difference in microspore composition of some samples from a bore at Comaum, South Australia. Aust. J. Bot., 7:462-473.

Cookson, I. C., and Dettmann, M. E., 1958. Some trilete spores from Upper Mesozoic deposits in the eastern Australian region. Proc. R. Soc. Victoria, 70:95-128.

Cookson, I. C., and Eisenack, A., 1958. Microplankton from Australian and New Guinea Upper Mesozoic sediments. Proc. R. Soc. Victoria, 70:19-79.

1960. Upper Mesozoic microplankton from Australia and New Guinea. Palaeontology, 2:243-261.

1962. Additional microplankton from Australian Cretaceous sediments. Micropaleontology, 8:485-507:

Couper, R. A., 1953. Upper Mesozoic and Cainozoic spores and pollen grains from New Zealand. Paleontol. Bull. N.Z. Geol. Surv., 22:1-77.

Dale, B., 1983. Dinoflagellate resting cysts: "benthic plankton." In Fryxell, G. A. (Ed.), Survival Strategies of the Algae: Cambridge (Cambridge Univ. Press), 69-136.

Davey, R. J., 1969. Non-calcareous microplankton from the Cenomanian of England, northern France and North America, Part I. Bull. Brit. Mus. Nat. Hist. (Geol.), 17:103-180.

1970. Non-calcareous microplankton from the Cenomanian of England, northern France and North America, Part II. Bull. Brit. Mus. Nat. Hist. (Geol.), 18:333-397.

1974. Dinoflagellate cysts from the Barremian of the Speeton Clay, England. Spec. Publ. Birbal Sahni Inst. Palaeobot., 3:41-75.

-1988. Palynological zonation of the Lower Cretaceous, Upper and uppermost Middle Jurassic in the Northwestern Papuan Basin of Papua, New Guinea. Mem.-Geol. Surv. Papua, New Guinea, 13:1-77.

Davey, R. J., Downie, C., Sarjeant, W.A.S., and Williams, G. L., 1969. Generic reallocations. In Davey, R. J., Downie, C., Sarjeant, W.A.S., and Williams, G. L. (Ed.), Appendix to Studies on Mesozoic and Cainozoic Dinoflagellate Cysts. Suppl. Bull. Brit. Mus. Nat. Hist. (Geol.), 3:15-17.

Davey, R. J., and Williams, G. L., 1966. The genus Hystrichosphaeridium and its allies. In Davey, R. J., Downie, C., Sarjeant, W.A.S., and Williams, G. L. (Ed.), Studies on Mesozoic and Cainozoic Dinoflagellate Cysts. Suppl. Bull. Brit. Mus. Nat. Hist. (Geol.), 3:53-106.

, 1969. Generic reallocations. In Davey, R. J., Downie, C., Sarjeant, W.A.S., and Williams, G. L. (Eds.), Appendix to studies on Mesozoic and Cainozoic Dinoflagellate Cysts. Suppl. Bull. Brit. Mus. Nat. Hist. (Geol.), 3:4-7.

Deflandre, G., 1937. Microfossiles des silex crétacés. Deuxième partie. Flagellés incertae sedis Hystrichosphaeridés. Sarcodinés. Organismes divers. Ann. Paleontol., 26:51-103.

Deflandre, G., and Cookson, I. C., 1955. Fossil microplankton from Australian Late Mesozoic and Tertiary sediments. Aust. J. Mar. Freshwater Res., $6: 242-313$.

Deflandre, G., and Courteville, H., 1939. Note préliminaire sur les microfossiles des silex crétacés du Cambrésis. Bull. Soc. Fr. Microscr., 8:95-106.

Delcourt, A. F., and Sprumont, G., 1955. Les Spores et Grains du Pollen du Wealdenien du Hainaut. Mem. Soc. Belge Geol., 5:1-73.

Dettmann, M. E., 1963. Upper Mesozoic microfloras from south-eastern Australia. Proc. R. Soc: Victoria, 77:1-148.
Dev, S., 1961. The fossil flora of the Jabalpur Series-3. Spores and Pollen grains. Palaeobotanist, 8:43-56.

Dörhöfer, G., 1977. Palynologie und Stratigraphie der Bückeberg-Formation (Berriasium-Valaginium) in der Hilsmulde (NW-Deutschland). Geol. Jahrb. Reihe A, 42:3-122.

Dürr, G.,1988. Palynostratigraphie des Kimmeridgium und Tithonium von Süddeutschland und Korrelation mit borealen Floren. Tübinger Mikropaläontol. Mitt., 5:1-159.

Duxbury, S., 1977. A palynostratigraphy of the Berriasian to Barremian of the Speeton Clay of Speeton, England. Palaeontographica B, 160:17-67.

Eisenack, A., and Cookson, I. C., 1960. Microplankton from Australian Lower Cretaceous sediments. Proc. R. Soc. Victoria, 72:1-11.

Gocht, H., 1957. Mikroplankton aus dem nordwestdeutschen Neokom (Teil I). Palaeontol. Z., 31:163-185.

, 1959. Mikroplankton aus dem nordwestdeutschen Neokom (Teil II). Palaeontol. Z., 33:50-89.

Habib, D., 1972. Dinoflagellate stratigraphy Leg 11, Deep Sea Drilling Project. In Hollister, C. D., Ewing, J. 1., et al., Init. Repts. DSDP, 11: Washington (U.S. Govt. Printing Office), 367-425.

1978. Palynostratigraphy of the Lower Cretaceous Section at DSDP Site 391, Blake-Bahama Basin, and its correlation in the North Atlantic. In Benson, W. E., Sheridan, R. E., et al., Init. Repts. DSDP, 44: Washington (U.S. Govt. Printing Office), 887-898.

Habib, D., and Drugg, W. S., 1987. Palynology of Sites 603 and 605, Leg 93, Deep Sea Drilling Project. In van Hinte, J. E., Wise, S. W., Jr., et al., Init. Repts. DSDP, 93 (Pt. 2): Washington (U.S. Govt. Printing Office), 751-775.

Helby, R., Morgan, R., and Partridge, A. D., 1987. A palynological zonation of the Australian Mesozoic. In Jell, P. A. (Ed.), Studies in Australian Mesozoic Palynology. Mem. Assoc. Australas. Palaeontol., 4:1-94.

Helby, R., Wilson, G. J., and Grant-Mackie, J. A., 1988. A preliminary biostratigraphic study of Middle to late Jurassic dinoflagellate assemblages from Kawhia, New Zealand. In Jell, P. A., and Playford, G. (Eds.), Palynological and Palaeobotanical Studies in Honour of Basil E. Balme. Mem. Assoc. Australas. Palaeontol., 5:125-166.

Jan du Chêne, R., Becheler, I., Helenes, J., and Masure, E., 1986. Les genres Diacanthum, Exiguisphaera, Occisucysta et Tehamadinium, gen. nov. (kystes fossiles de Dinoflagellés. Cah. Micropaleontol., 1:5-36.

Jell, P. A. (Ed.), 1987. Studies in Australian Mesozoic Palynology. Mem. Assoc. Australas. Palaeontol., 4:1-341.

Koreneva, E. V., 1980. Palynological study of samples from Sites 430, 431, 432, 433. In Jackson, E. D., Koizumi, I., et al., Init. Repts. DSDP, 55: Washington (U.S. Govt. Printing Office), 409-413.

Loeblich, A. R., III, and Loeblich, L. A., 1984. Dinoflagellate Cysts. In Spector, D. L. (Ed.), Dinoflagellates: New York (Academic Press), 443-480.

Lowrie, W., Channell, J.E.T., and Alvarez, W., 1980. A review of magnetic stratigraphy investigations in Cretaceous pelagic carbonate rocks. J. Geophys. Res., 85:3597-3605.

May, F. E., 1980. Dinoflagellate cysts of the Gymnodiniaceae, Peridiniaceae, and Gonyaulacaceae from the Upper Cretaceous Monmouth Group, Atlantic Highlands, New Jersey. Palaeontographica B, 172:10-116.

McNutt, M. K., Winterer, E. L., Sager, W. W., Natland, J. H., and Ito, G., 1990. The Darwin Rise: a Cretaceous superswell? Geophys. Res. Lett., 17:1101-1104.

Mehrotra, N. C., and Sarjeant, W.A.S., 1984. Dingodinium, a dinoflagellate cyst genus exhibiting variation in archaeopyle character. Micropaleontology, 30:292-305.

Ogg, J. G., 1988. Early Cretaceous and Tithonian magnetostratigraphy of the Galicia Margin (Ocean Drilling Program Leg 103). In Boillot, G., Winterer, E. L., et al., Proc. ODP, Sci. Results, 103: College Station, TX (Ocean Drilling Program), 659-682.

Pocock, S.A.J., 1962. Microfloral analysis and age determination of the strata at the Jurassic-Cretaceous boundary in the western Canada Plains. $\mathrm{Pa}$ laeontographica B, 111:1-95.

1964. Pollen and spores of the Chlamydospermidae and Schizaeaceae from upper Mannville strata of the Saskatoon area of Saskatchewan. Grana Palynol., 5:129-209.

Potonié, R., 1956. Synopsis der Gattungen der Sporae dispersae. 1. Teil; Sporites. Beih. Geol. Jahrb., 23:1-103.

Roth, P. H., 1973. Calcareous nannofossils-Leg 17, Deep Sea Drilling Project. In Winterer, E. L., Ewing, J. I., et al., Init. Repts. DSDP, 17: Washington (U.S. Govt. Printing Office), 695-795.

Sarjeant, W.A.S., 1966. Dinoflagellate cysts with Gonyaulax-type tabulation. In Davey, R. J., Downie, C., Sarjeant, W.A.S., and Williams, G. L. (Ed.), Studies on Mesozoic and Cainozoic Dinoflagellate Cysts. Suppl. Bull. Brit. Mus. Nat. Hist. (Geol.), 3:107-156. 
Sayre, W. O., 1981. Preliminary report on the paleomagnetism of Aptian and Albian limestones and trachytes from the Mid-Pacific Mountains and Hess Rise, Deep Sea Drilling Project, Leg 62. In Thiede, J., Vallier, T. L., et al., Init. Repts. DSDP, 62: Washington (U.S. Govt. Printing Office), 983-994.

Shipboard Scientific Party, 1973a. Site 167. In Winterer, E. L.. Ewing, J. I., et al., Init. Repts. DSDP, 17: Washington (U.S. Govt. Printing Office), 145-234.

1973b. Mesozoic chalk and chert on the Pacific Plate near Japan: DSDP Site 195. In Heezen, B. C., MacGregor, I. D., et al., Init. Repts. DSDP, 20: Washington (U.S. Govt. Printing Office), 19-32.

,1973c. Pliocene volcanogenic sediments and Mesozoic chalks southeast of Japan: DSDP Site 196. In Heezen, B. C., MacGregor, I. D., et al., Init Repts. DSDP, 20: Washington (U.S. Govt. Printing Office), 33-44.

1981. Site 463: Western Mid-Pacific Mountains. In Boillot, G., Winterer, E. L., Meyer, A. W., et al., Proc. ODP, Init. Repts, 103: College Station, TX (Ocean Drilling Program), 33-156.

, 1990a. Site 800. In Lancelot, Y., Larson, R., et al., Proc. ODP, Init. Repts, 129: College Station, TX (Ocean Drilling Program), 33-89.

1990b. Site 801. In Lancelot, Y., Larson, R., et al., Proc. ODP, Init. Repts, 129: College Station, TX (Ocean Drilling Program), 91-170.

1990c. Site 802. In Lancelot, Y., Larson, R., et al., Proc. ODP, Init. Repts, 129: College Station, TX (Ocean Drilling Program), 171-243.

Sliter, W., 1989. Aptian anoxia in the Pacific Basin. Geology, 17:909-912.

Stevens, J., 1987. Some Early Cretaceous dinoflagellates from the Cassiculosphaeridia delicata Zone on the Exmouth Plateau, Western Australia. In Jell, P. A. (Ed.), Studies in Australian Mesozoic Palynology. Mem. Assoc. Australas. Palaeontol., 4:185-197.

Stover, L. E., and Evitt, W. R., 1978. Analyses of pre-Pleistocene organicwalled dinoflagellates. Stanford Univ. Publ. (Geol. Sci.), 15:1-300.
Stover, L. E., and Helby, R., 1987. Some Early Cretaceous dinoflagellates from the Houtman-1 well, Western Australia. In Jell, P. A. (Ed.), Studies in Australian Mesozoic Palynology. Mem. Assoc. Australas. Palaeontol., 4:261-295.

Tarduno, J. A., Sliter, W. V., Bralower, T. J., McWilliams, M., Premoli-Silva, I., and Ogg, J. G., 1989. M-sequence reversals recorded in DSDP sediment cores from the western Mid-Pacific Mountains and Magellan Rise. Geol. Soc. Am. Bull., 101:1306-1316.

Vogt, P. R., 1989. Volcanogenic upwelling of anoxic, nutrient-rich water: a possible factor in carbonate-bank/reef demise and benthic faunal extinctions. Geol. Soc. Am. Bull., 101:1225-1245.

Wetzel, O., 1933. Die in organischer Substanz erhaltenen Mikrofossilien des baltischen Kreide-Feuersteins mit einem sediment-petrographischen und stratigraphischen Anhang. Palaeontographica A, 77:141-188.

White, H. H., 1842. On fossil Xanthidia. Microsc. J. London, 11:35-40.

Wilson, L. R., and Webster, R. M., 1946. Plant microfossils from a Fort Union Coal of Montana. Am. J. Bot., 33:271-278.

Winterer, E. L., and Metzler, C., 1984. Origin and subsidence of guyots in Mid-Pacific Mountains. J. Geophys. Res., 89:9969-9979.

Wiseman, J. F., 1976. Palynological investigation of samples from Holes 319 , 320, 320A, and Site 321 of DSDP Leg 34. In Yeats, R. S., Hart, S. R., et al., Init. Repts. DSDP, 34: Washington (U.S. Govt. Printing Office), 741-742.

Date of initial receipt: 20 May 1991

Date of acceptance: 17 March 1992

Ms 129B-122

\section{Sporomorph distribution}

- common

abundant rare

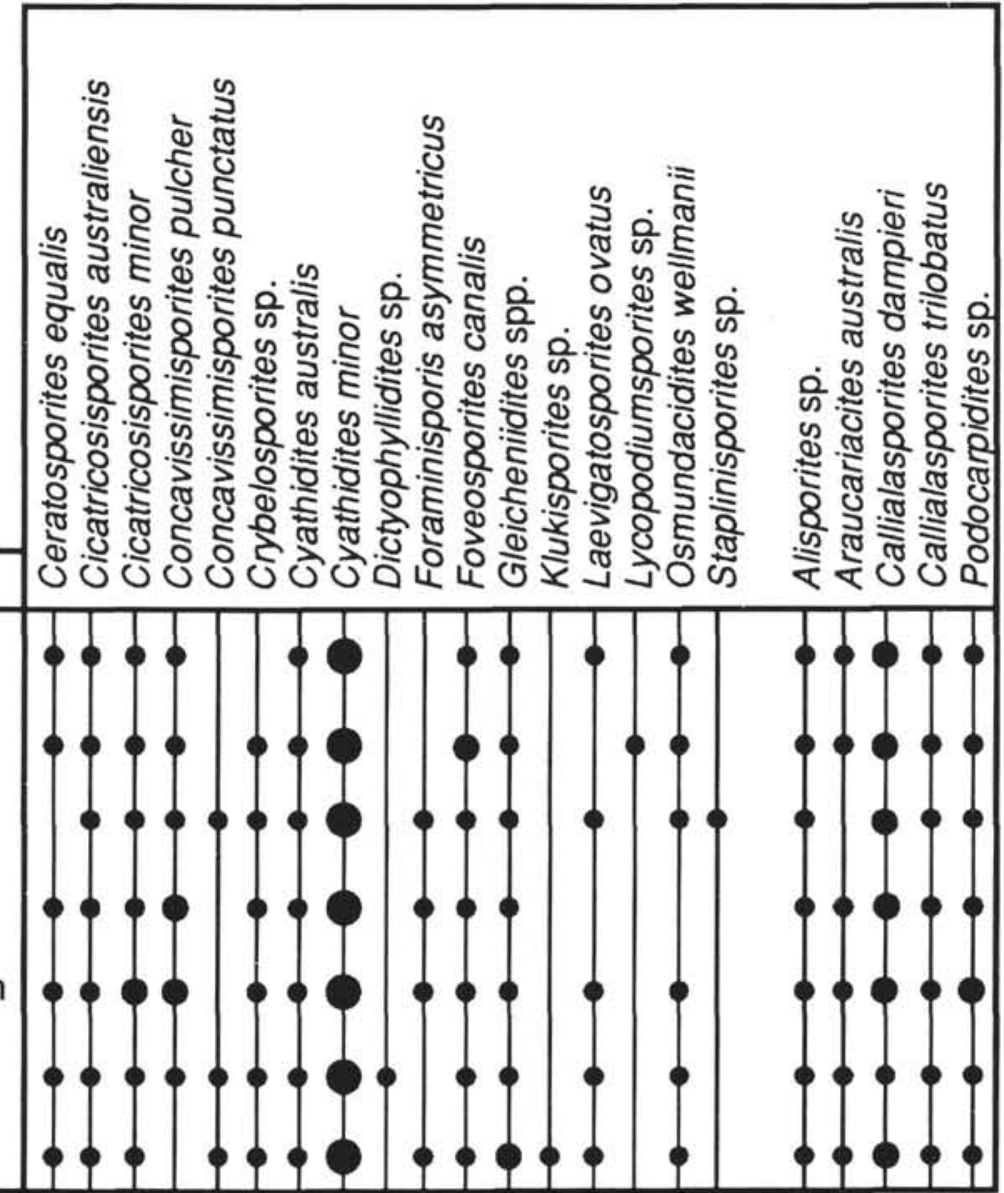

Figure 3. Distribution of spores and pollen grains in Hole 802A. 


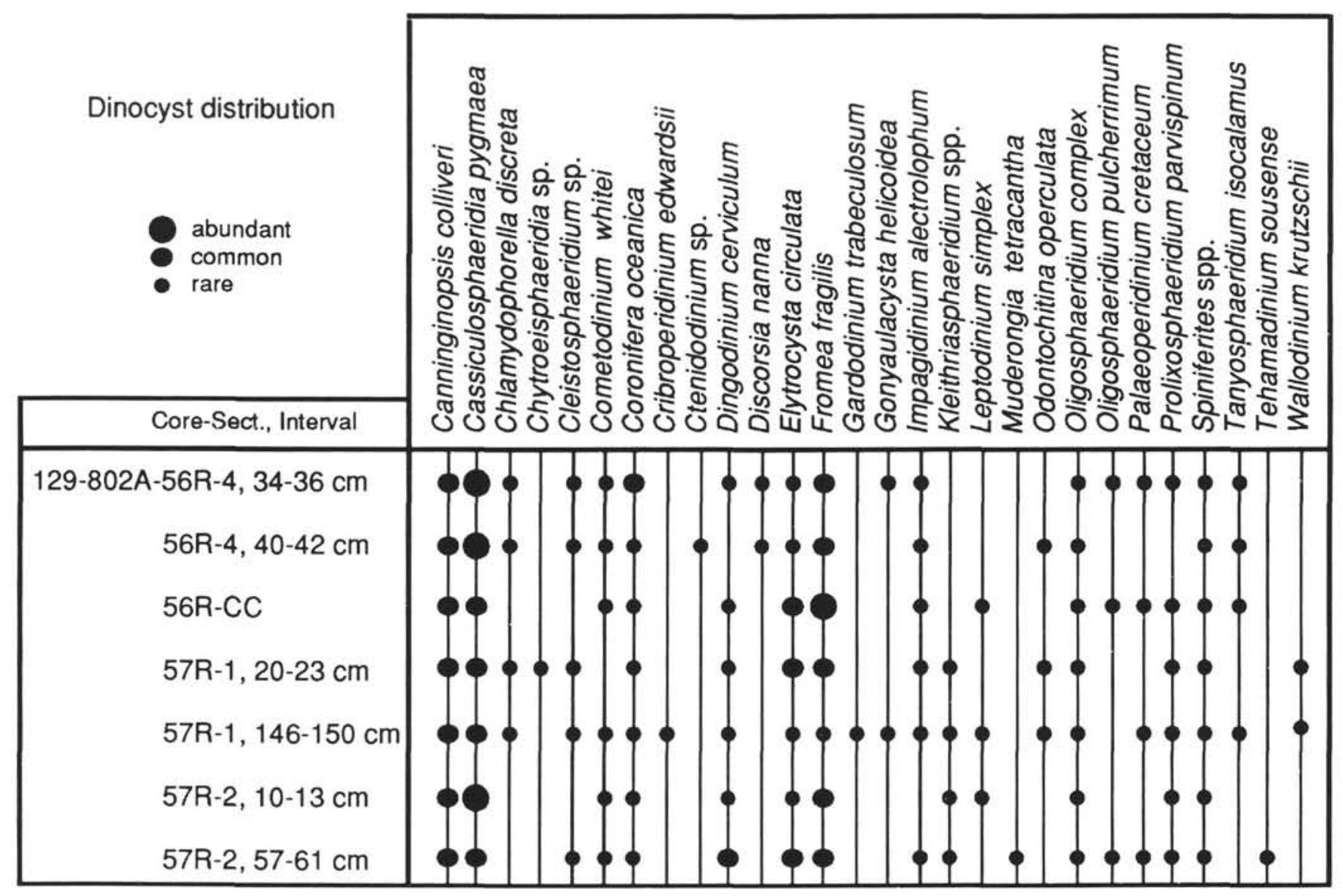

Figure 4. Distribution of dinoflagellate cysts in Hole 802A.

\begin{tabular}{|c|c|c|c|c|}
\hline Age & sZ & Dinocyst zones & $S Z$ & Sporomorph zones \\
\hline \multirow{6}{*}{$\frac{c}{\frac{c}{0}}$} & \multirow{5}{*}{ 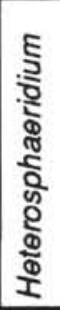 } & Xenascus & \multirow{5}{*}{$\begin{array}{l}\frac{n}{5} \\
8 \\
\frac{2}{2} \\
8 \\
\Phi \\
0 \\
1\end{array}$} & \\
\hline & & asperatus & & \multirow{2}{*}{$\begin{array}{l}\text { Phimopollenites } \\
\text { pannosus }\end{array}$} \\
\hline & & \multirow{2}{*}{$\begin{array}{l}\text { Pseudoceratium } \\
\text { ludbrookiae }\end{array}$} & & \\
\hline & & & & \multirow[b]{2}{*}{$\begin{array}{l}\text { Coptospora } \\
\text { paradoxa }\end{array}$} \\
\hline & & $\begin{array}{l}\text { Canninginopsis } \\
\text { denticulata }\end{array}$ & & \\
\hline & \multirow{4}{*}{ 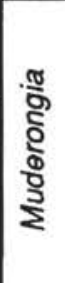 } & $\begin{array}{l}\text { Muderongia } \\
\text { tetracantha }\end{array}$ & \multirow{4}{*}{ 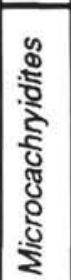 } & \multirow{2}{*}{$\begin{array}{l}\text { Crybelosporites } \\
\text { striatus }\end{array}$} \\
\hline \multirow{3}{*}{$\begin{array}{l}c \\
\underset{\pi}{\square} \\
\frac{a}{\alpha}\end{array}$} & & \multirow{2}{*}{$\begin{array}{l}\text { Diconodinium } \\
\text { davidii }\end{array}$} & & \\
\hline & & & & \multirow{2}{*}{$\begin{array}{l}\text { Cyclosporites } \\
\text { hughesii }\end{array}$} \\
\hline & & $\begin{array}{l}\text { Odontochitina } \\
\text { operculata }\end{array}$ & & \\
\hline
\end{tabular}

Figure 5. Aptian/Albian dinoflagellate cyst and sporomorph zonation scheme of Australia (Helby et al., 1987). 


\section{APPENDIX}

\section{Dinoflagellate Cysts}

Site 802

Canninginopsis colliveri (Cookson and Eisenack, 1960) Backhouse, 1988

Cassiculosphaeridia pygmaea Stevens, 1987

Cleistosphaeridium spp.

Chlamydophorella discreta Clarke and Verdier, 1967

Chytroeisphaeridia sp.

Cometodinium ?whitei (Deflandre and Courteville,1939) Stover and Evitt, 1978

Coronifera oceanica Cookson and Eisenack, 1958, emend. May 1980

Cribroperidinium edwardsii (Cookson and Eisenack, 1958) Davey, 1969

Ctenidodinium sp.

Dingodinium cerviculum Cookson and Eisenack, 1958 emend. Mehrotra and Sarjeant, 1984

Discorsia nanna (Davey, 1974) Duxbury, 1977

Elytrocysta circulata (Clarke and Verdier, 1967), Stover and Helby, 1987

Fromea fragilis (Cookson and Eisenack, 1962) Stover and Evitt, 1978

Gardodinium trabeculosum (Gocht, 1959) Alberti, 1961

Gonyaulacysta helicoidea (Eisenack and Cookson, 1960) Sarjeant, 1966

Impagidinium alectrolophum (Sarjeant, 1966) Stover and Evitt, 1978

Kleithriasphaeridium spp.

Leptodinium simplex Burger 1980

Muderongia tetracantha (Gocht, 1957) Alberti, 1961

Odontochitina operculata (Wetzel, 1933) Deflandre and Cookson, 1955

Oligosphaeridium complex (White, 1842) Davey and Williams, 1966

Oligosphaeridium pulcherrimum (Deflandre and Cookson, 1955) Davey and Williams, 1966

Palaeoperidinium cretaceum Pocock, 1962, emend. Davey, 1970

Prolixosphaeridium parvispinum (Deflandre, 1937) Davey et al., 1969

Spiniferites spp.

Tanyosphaeridium isocalamus (Deflandre and Cookson, 1955) Davey and Williams, 1969

Tehamadinium sousense (Below, 1981) Jan du Chêne et al., 1986

Wallodinium krutzschii (Alberti, 1961) Habib, 1972

Site 167

Cleistosphaeridium spp.

Wallodinium krutzschii (Alberti, 1961) Habib, 1972

Site 463

Canninginopsis colliveri (Cookson and Eisenack, 1960) Backhouse, 1988

Chytroeisphaeridia sp.

Fromea fragilis (Cookson and Eisenack, 1962) Stover and Evitt, 1978

Impagidinium alectrolophum (Sarjeant, 1966) Stover and Evitt, 1978

Leptodinium simplex Burger 1980

Oligosphaeridium complex (White, 1842) Davey and Williams, 1966

Oligosphaeridium pulcherrimum (Deflandre and Cookson, 1955) Davey and Williams, 1966

Spiniferites spp.

Tanyosphaeridium isocalamus (Deflandre and Cookson, 1955) Davey and Williams, 1969

Wallodinium krutzschii (Alberti, 1961) Habib, 1972

\section{Acritarchs}

Site 802

Leiosphaeridia spp.

Micrhystridium spp.

Pterospermella sp.

Site 167

Micrhystridium spp.

Site 463

Leiosphaeridia spp.

Micrhystridium spp.

Pterospermella sp.

\section{Sporomorphs}

Site 802

Alisporites sp.

Araucariacites australis Cookson, 1947

Callialasporites dampieri (Balme 1957), Dev, 1961

Callialasporites trilobatus (Balme 1957), Dev, 1961

Ceratosporites equalis Cookson and Dettmann, 1958

Cicatricosisporites australiensis (Cookson 1953) Potonié, 1956

Cicatricosisporites minor (Bolchovitina 1961) Pocock, 1964

Concavissimisporites pulcher Dörhöfer, 1977

Concavissimisporites punctatus (Delcourt and Sprumont, 1955) Brenner, 1963

Crybelosporites $\mathrm{sp}$.

Cyathidites australis Couper, 1953

Cyathidites minor Couper, 1953

Dictyophyllidites $\mathrm{sp}$.

Foraminisporis asymmetricus (Cookson and Dettmann, 1958) Dettmann, 1963

Foveosporites canalis Balme, 1957

Gleicheniidites spp.

Klukisporites sp.

Laevigatosporites ovatus Wilson and Webster, 1946

Lycopodiumsporites $\mathrm{sp}$.

Osmundacidites wellmanii Couper, 1953

Podocarpidites sp.

Staplinisporites sp.

Site 463

Callialasporites dampieri (Balme 1957), Dev, 1961

Cicatricosisporites australiensis (Cookson 1953) Potonié, 1956

Cicatricosisporites minor (Bolchovitina 1961) Pocock, 1964

Cyathidites australis Couper, 1953

Cyathidites minor Couper, 1953

Gleicheniidites spp.

Leptolepidites sp.

Osmundacidites wellmanii Couper, 1953

Podocarpidites sp.

Stereisporites antiquasporites (Wilson and Webster, 1946) Dettmann, 1963 


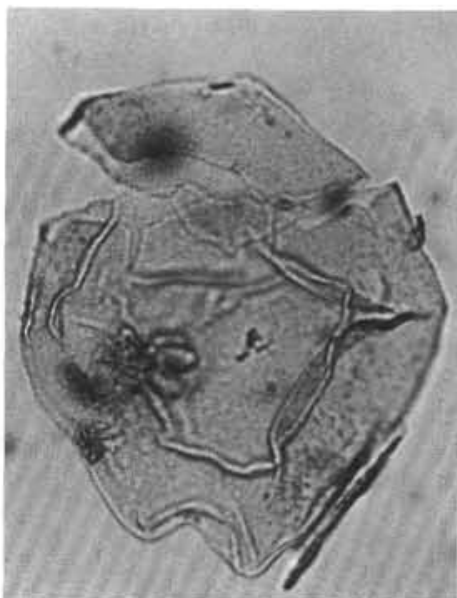

1

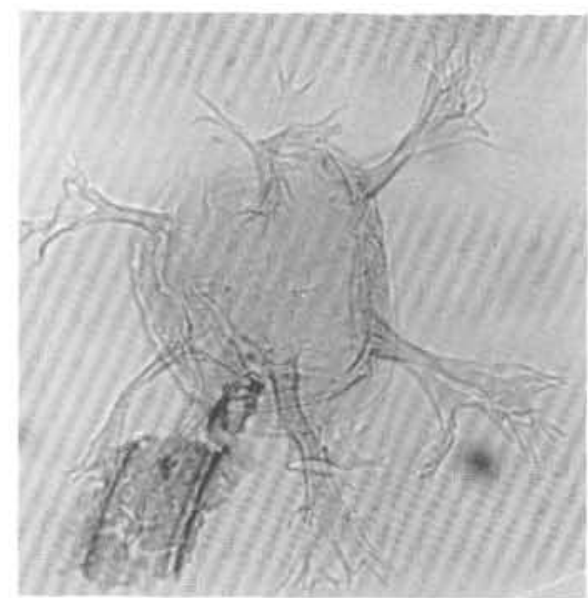

4

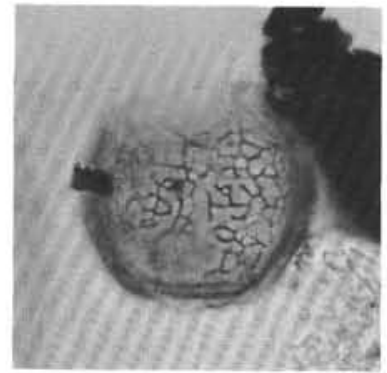

7

2

8
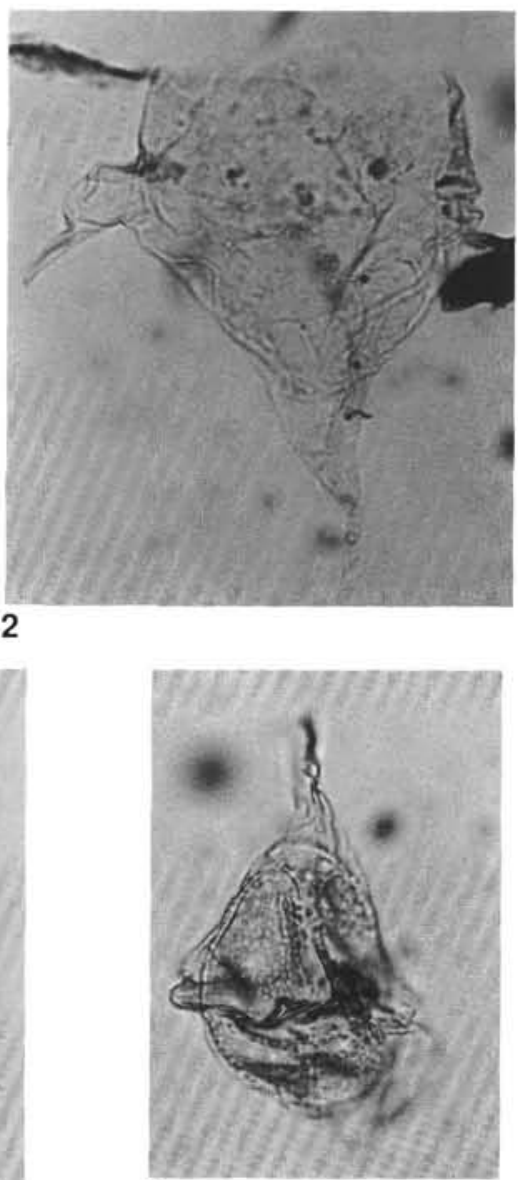

5

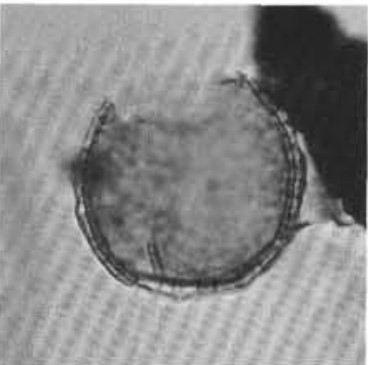

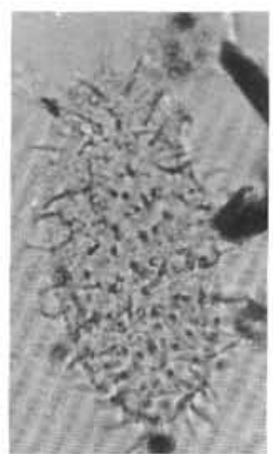

9

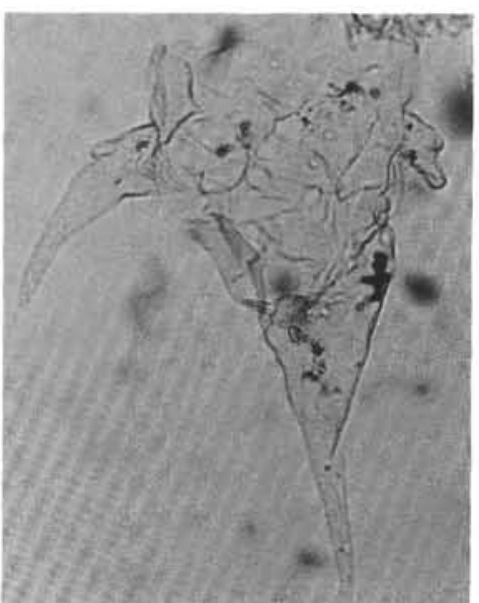

3

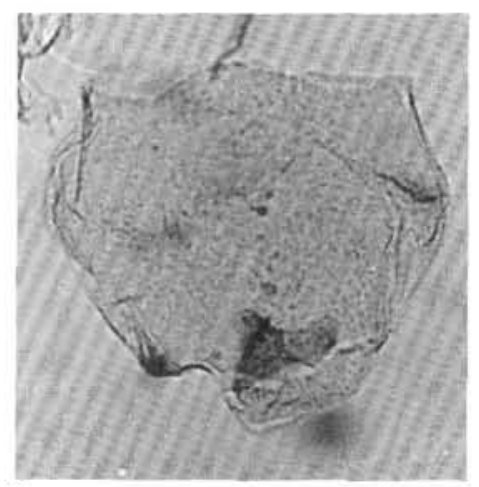

6

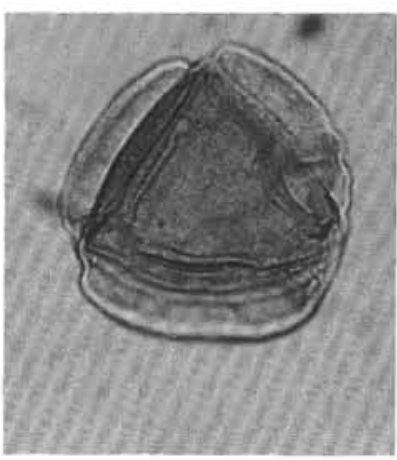

10

Plate 1. Photomicrographs of palynomorphs. Magnification 600X. 1. Canninginopsis colliveri, Sample 129-802A-57R-2, 57-61 cm, slide e. 2. Muderongia tetracantha, Sample 129-802A-57R-2, 57-61 cm, slide e. 3. Muderongia tetracantha, Sample 129-802A-57R-2,57-61 cm, slide e. 4. Oligosphaeridium complex, Sample 129-802A-56R-4, 40-42 cm, slide b. 5. Dingodinium cerviculum, Sample 129-802A-57R-2, 57-61 cm, slide e. 6. Canninginopsis colliveri, Sample 129-802A-57R-2, 57-61 cm, slide e. 7, 8. Elytrocysta circulata. Sample 129-802A-57R-1, 20-23 cm, slide a. 9. Prolixosphaeridium parvispinosum, Sample 129-802A-57R-2, 10-13 cm, slide a. 10. Callialasporites trilobatus, Sample 129-802A-56R-4, 40-42 cm, slide d. 